\title{
TRAUMATIC SHOCK. VII. A STUDY OF THE PROBLEM OF THE "LOST PLASMA" IN HEMORRHAGIC, TOURNIQUET, AND BURN SHOCK BY THE USE OF RADIOACTIVE IODO-PLASMA PROTEIN ${ }^{1}$
}

\author{
By JACOB FINE AND ARNOLD M. SELIGMAN \\ (From the Surgical Research Department, Beth Israel Hospital, Boston, and \\ the Department of Surgery, Harvard Medical School, Boston)
}

(Received for publication November 24, 1943)

In paper IV of this series (1), evidence was given that there was no significant loss of plasma into the tissues of the dog in untreated fatal shock from hemorrhage. The technic utilized involved the tagging of plasma proteins by radioactive sulfur or radioactive bromine. Before extending the observations to shock in which there is an area of local injury, such as occurs in tourniquet and burn shock, an attempt was made to reduce the errors inherent in the radioactive technic (1 to 4$)$. These errors center in (1) the problem of obtaining the lowest possible halogen composition of the tagged protein in order to reduce denaturation of the protein to a minimum; (2) methods of determining the total intravascular plasma protein content of the tissues to be analyzed. This requires as accurate an estimate as can be made of the red cell fraction of the capillary blood. For this purpose, in addition to hemoglobin determinations of perhaps somewhat doubtful accuracy, estimates of the capillary hematocrit have been utilized. (3) The preparation of tissues for analysis so as to permit maximum recovery of the radioactive element. In preparing tissues containing radioactive bromo-protein for radioactivity measurements, an oxidative method of isolating the halogen was used. In the oxidation procedure, there was a possibility of loss of some bromine by volatilization in spite of the presence of $\mathrm{AgNO}_{3}$. Further, the excess bromide added as a carrier, together with the chloride also present, produced with silver nitrate a precipitate of sufficiently variable thickness and particle size to affect by self-absorption the accuracy of the radioactivity

\footnotetext{
1 The work described in this paper was done under a contract, recommended by the Committee on Medical Research, between the Office of Scientific Research and Development and Harvard University.
}

readings. There is also a possibility of some loss in the handling of the precipitates.

In respect to the first category of errors, a constant halogen composition of plasma proteins could be achieved by coupling the protein with a minimum of halogen, which is desirable for approximating the slowest possible rate of disappearance, i.e., the rate of disappearance of normal plasma protein from the blood of the normal dog (1). For this purpose, radioactive iodine proved more satisfactory than radioactive bromine. ${ }^{2}$ Hence, all experiments in this communication were performed with radioactive iodine exclusively.

In regard to the second group of errors, the hemoglobin determinations were probably not completely reliable and capillary hematocrits were only estimated. Nevertheless, on the basis of certain considerations to be described under "method," the probable error of these deficiencies was reduced to a minimum and, we have reason to believe, is not great enough to substantially affect the final results. As for the third group of errors, the oxidative method of isolating the radioactive halogen was abandoned and a method adopted involving evaporation to dryness (in the presence of alkali). The technic, described below, reduced the error of tissue analysis for radioactivity from 25 per cent to 10 per cent or less (compare Table I of this communication with Tables II and III of Paper III) (2).

\footnotetext{
2 Radio-iodine, prepared by the transmutation of tellurium, is obtained in arbitrarily high specific activity to which a constant minimum quantity $(5 \mathrm{mgm}$.) of carrier iodine is added for convenience in handling. On the other hand, radiobromine, which is prepared by neutron bombardment of large quantities of ethyl bromide, is unavoidably isolated with variable, but usually large quantities (300 mgm. or more) of non-radioactive bromine from hydrolysis of ethyl bromide.
} 
This communication provides data on the movement of plasma protein (and plasma) ${ }^{3}$ from the blood stream into the tissues of the normal dog and of the dog shocked by hemorrhage, a tourniquet, or a burn. The well-known observation that dogs in irreversible shock show wet or hemorrhagic tissues if treated by infusions, particularly of saline, required a special study of the state of capillary permeability in these circumstances. The data to be presented agree with those already reported, to the effect that there is no evidence to substantiate the common belief that a progressively increasing loss of plasma protein and plasma from the generalized capillary bed occurs in shock. Loss occurs only into areas of injury such as produced by a tourniquet or burn. Some of the data and conclusions from this work are already reported elsewhere (5).

\section{METHOD}

All dogs received morphine sulfate, $2.0 \mathrm{mgm}$. per $\mathrm{kgm}$. body weight. Larger doses were administered before the application of a tourniquet. Burns were produced under ether anesthesia. Barbiturates were not used, since the resistance of dogs to shock procedures was found to be markedly reduced by even small doses of nembutal (see experiment I-5).

Hemorrhagic shock was induced as described previously (1). Normal dogs served as controls for the dogs in shock. When we studied the possibility of abnormal escape of plasma protein in the stages of shock which do not respond to transfusion, i.e., "irreversible shock," a dog in shock which did respond to a transfusion served as the

\footnotetext{
8 The capillary leakage hypothesis assumes that plasma (or some of its constituents) escapes from the general capillary bed at a greater than normal rate and that it fails to return to the circulation as fast as it leaves, resulting in a net gain of plasma to tissues outside of localized areas of injury. Since the net loss of the non-protein fraction of plasma without a simultaneous net loss of some protein from the circulation will not produce shock (except in the case of shock from extreme and rapid dehydration), a determination of the presence or absence of a net gain of plasma protein to the extravascular portion of the tissues outside of areas of injury should decide whether or not this hypothesis is tenable. In the subsequent discussion, therefore, while the data obtained refer only to protein shifts, we shall not distinguish between plasma protein loss and whole plasma loss when referring to the concept of leakage due to a generalized increase in capillary permeability. For the purpose at hand, it is not so necessary to demonstrate the existence of an increase in capillary permeability as it is to observe the consequences of such an increase.
}

control. Radioprotein was injected with the transfusion or with subsequent saline infusions.

Tourniquet shock was induced by applying 5 to 6 turns of heavy-walled rubber tubing as high on the leg as possible, as tightly as possible, and held with a screw clamp. Previous investigators who employed barbiturate anesthesia produced fatal shock if a tourniquet was applied for 5 hours. In our experiments, in which barbiturate anesthesia was not used, fatal shock did not occur unless the tourniquet (one leg) was left on at least 8 to 9 hours. Normal dogs were used as controls. Radioactive protein was injected one-half hour before the tourniquet was removed.

Burns were produced by immersion of 1 or 2 extremities in hot water $\left(98^{\circ} \mathrm{C}\right.$.) for varying periods of time. In contrast to the observations of others (6), who used barbiturate anesthesia, we did not produce fatal shock by immersion in water at $98^{\circ} \mathrm{C}$. for 20 seconds. In one experiment (I-5, Table V), immersion of 2 legs in water at $98^{\circ} \mathrm{C}$. for 45 seconds did not produce fatal shock, but administration of a small amount of nembutal intraperitoneally, 24 hours later, produced a drop in blood pressure to $30 \mathrm{~mm}$. $\mathrm{Hg}$ followed by death. For this reason, burns for longer periods of time were used. In such cases, marked hemoglobinemia was produced. Normal dogs were used as controls. In one experiment (I-8), a dog receiving a non-fatal burn was used as a control for a dog with fatal burn shock. Radioactive protein was injected one-half hour before the animal was burned (except in experiment I-8).

\section{PREPARATION OF RADIOACTIVE IODO- PLASMA PROTEIN}

A target of cobalt telluride, having received deuteron bombardment for $\mathbf{4 0 0}$ microampere hours, was filed from its copper base and transferred to an all glass distillation apparatus. A desired amount of carrier iodine ( 2 to 5 $\mathrm{mgm}$.) was added as a potassium iodide solution $(1.0 \mathrm{ml}$. containing $5.0 \mathrm{mgm}$. of iodine) followed by $20 \mathrm{ml}$. of 30 per cent nitric acid. After the evolution of the nitrogen peroxide had ceased, iodine was rapidly distilled into cold carbon tetrachloride $(25 \mathrm{ml}$.) and a few $\mathrm{ml}$. of water. At the end of the distillation, the water was run out of the condenser, and the steam was allowed to bubble through the carbon tetrachloride for a few seconds to sweep out all iodine from the condenser. The carbon tetrachloride solution was then washed once with a few $\mathrm{ml}$. of water.

The carbon tetrachloride solution of iodine was then added with swirling in the cold to $50 \mathrm{ml}$. of plasma (previously extracted once with carbon tetrachloride) or to $20 \mathrm{ml}$. of a 10 per cent solution of crystallized bovine albumin, followed by $10 \mathrm{ml}$. of 25 per cent sodium carbonate solution. ${ }^{4}$ "The violet color of the carbon tetrachloride solution was rapidly discharged on shaking. The mixture was centrifuged and the plasma separated and dialyzed

4 The undesirability of using stronger alkali was discussed in a previous publication (1). 
against cold running tap water for 36 to 48 hours. The percentage of radio-iodine incorporated in the plasma protein was 15 per cent of the amount used. When 5.0 mgm. of iodine were used as a carrier and about $50 \mathrm{ml}$. of plasma iodinated, the percentage of iodine in the iodoprotein was about 0.03 per cent. If one molecule of iodine had been incorporated per protein molecule, the plasma protein would have contained about 0.2 per cent of iodine, which is the theoretical upper limit of iodine content for obtaining the slowest possible rate of disappearance of a haloginated protein from the circulating plasma (see previous discussion (1) in the case of bromine). By the time tissue radioactivity measurements were made (5 to 10 days after the bombardment), most of the $I^{100}$ (half life, 13 hours) had disintegrated, and the radiation was essentially that of $I^{131}$ (half life, 8 days). The latter constitutes about 10 per cent of the total original radiation.

\section{STABILITY OF THE IODINE LINKAGE IN IODINATED PLASMA PROTEIN}

Following 40 hours of dialysis, about 2 per cent of the total radioactivity was found in the non-protein fraction after precipitation of the protein with trichloroacetic acid. Trypsin hydrolysis at $37^{\circ} \mathrm{C}$. for 6 hours at $\mathrm{pH} 8.0$ released 4.0 per cent of the radioactive iodine content of the protein into the non-protein fraction. Acid hydrolysis with 25 per cent sulfuric acid at $90^{\circ} \mathrm{C}$. for 6 hours resulted in 40 per cent of the total radioactivity in the non-protein fraction. The stability of the iodine linkage is similar to the bromine linkage, referred to in a previous publication (1), in alkaline enzymatic hydrolysis, but much weaker in strong acid. Previous workers (7) have shown that small amounts of ionic radio-iodine are immediately removed from the blood stream by the thyroid gland. That no great increase in ionic iodine occurred in vivo can be inferred from the fact that the thyroid content of radioactive iodine in a normal dog did not rise during a 12-hour period above 0.1 per cent of the radioactive iodine injected as iodoprotein.

\section{PREPARATION OF PLASMA AND TISSUES CON- TAINING RADIOACTIVE IODINE FOR RADIOACTIVITY ANALYSIS}

Heparinized plasma (1.0 ml.) was evaporated to dryness in small brass cups at about $80^{\circ} \mathrm{C}$. Tissues (4.0 grams) were hydrolyzed by heating at 80 to $90^{\circ} \mathrm{C}$. in an oven with $25 \mathrm{ml}$. of IN NaOH in $50 \mathrm{ml}$. beakers covered with a watch glass. After the tissues had dissolved, the watch

5y keeping the iodine content well below this upper limit, the chances of a given protein molecule coupling with more than one iodine molecule were reduced to a minimum.

- Oxidation of tissues with nitric acid in the presence of silver nitrate, as described for radioactive bromine experiments $(1,2)$, resulted in volatilization of large amounts of iodine. glass was removed and concentration allowed to proceed to 10 to $15 \mathrm{ml}$. The solution was transferred to a graduate and made up to $20 \mathrm{ml}$. with water. After thorough mixing, $5.0 \mathrm{ml}$. were pipetted to a glass cup and evaporated to dryness. Because of the hygroscopic nature of the dry alkali, the cups were re-evaporated on the following day and kept in pill boxes until just before radioactivity measurements were made. Dry weights so prepared varied from 600 to $800 \mathrm{mgm}$., but the dry weights of similar organs in different dogs agreed within $100 \mathrm{mgm}$. The dry weight per sq. $\mathrm{cm}$. of exposed-surface was about 80 to $90 \mathrm{mgm}$. (glass cups were $34 \mathrm{~mm}$. in diameter).

Greater ease and accuracy in pipetting the solutions was obtained when lean animals were used, since excessive fat in some tissues (especially skin) resulted in soap formation with marked increase in viscosity. When the heating was kept to a minimum, it was possible to dissolve all tissue constituents except fat. Since the fat floated as an oil and contained none of the iodine, it was partially separated from the aqueous solution and discarded.

In order to correlate measurements of plasma $(1.0 \mathrm{ml}$. in brass cups) with those of tissues (1.0 gram in $5 \mathrm{ml}$. glass cups) for subsequent calculations, 2 standards from the radioactive protein used for injection were prepared by dilution 50 times with dog plasma. One ml. was treated as for plasma, and $0.1 \mathrm{ml}$. was evaporated in a glass cup with 5 to $6 \mathrm{ml}$. of dog plasma and $0.5 \mathrm{ml}$. of $10 \mathrm{~N} \mathrm{NaOH}$. In this way, the same order of activity and dry weight was approximated.

In the experiment in which red cells containing radioactive iron were used, it was necessary to prepare standards from which corrections could be made for the radioactivity of tissues contributed by the red cell content. To 2 glass cups containing $0.5 \mathrm{ml}$. of $10 \mathrm{~N} \mathrm{NaOH}$ and 5 to $6 \mathrm{ml}$. of dog plasma were added $(A) 0.1 \mathrm{ml}$. arterial blood (taken at the time of death) and $(B) 0.1-\frac{\text { arterial hematocrit }}{10} \mathrm{ml}$. of plasma (taken at the time of death). The measurement of $A-B$ gave the activity of $\frac{\text { arterial hematocrit }}{10} \mathrm{ml}$. of red blood cells. From this, the activity of tissue due to a measured volume of radioactive cells could be calculated. It was always very small in comparison to the activity of iodoprotein.

\section{MEASUREMENT OF RADIOACTIVITY}

Radioactivity measurements were made with an electroscope. The modifications incorporated for measuring radioactive sulfur and bromine (2) were extended for radioactive iodine so as to take a $5.0 \mathrm{ml}$. capacity glass cup referred to above. The use of the larger cup was necessary for measuring the activity in 1.0 gram of tissue, since hydrolyzed tissue required $5.0 \mathrm{ml}$. of solution per gram for accuracy in pipetting. Had smaller amounts of tissue been measured, more radioactive iodoprotein would have been required for injection. The sliding bar of the electroscope (2) was enlarged to take the larger cup, and a shallow socket was made in the center of the floor of the 
TABLE I

Comparison of measurements of 1.0 gram samples of liver to which were added various dilutions of radioactive iodoprotein*

\begin{tabular}{c|l|c|c}
\hline Dilutions & Radioactivity & $\begin{array}{c}\text { Deviation } \\
\text { from } \\
\text { linearity }\end{array}$ & $\begin{array}{c}\text { Ratio of } \\
\text { radiactivity } \\
\text { to backgtound }\end{array}$ \\
\hline & $\begin{array}{c}\text { divisions } \\
\text { per second }\end{array}$ & per cent & \\
1 & 0.00303 & -1 & 56 \\
2 & 0.00150 & -2 & 28 \\
4 & 0.000768 & 0 & 14 \\
8 & 0.000368 & -4 & 7 \\
\hline 1 & 0.000505 & 0 & 9 \\
3 & 0.000188 & +10 & 3 \\
9 & 0.0000632 & +11 & 1 \\
\hline Background & 0.0000532 &
\end{tabular}

* Error was greater when radioactivity was nearer background.

large cup socket to hold the $1.0 \mathrm{ml}$. brass cups. In this way, the large glass cup and the small brass cup could be used for measurement of radio-iodoprotein, in 1 gram of tissue and $1 \mathrm{ml}$. of plasma, respectively. Since the larger sliding bar displaced much more air within the chamber, difficulty in keeping a constantly dry atmosphere was encountered. This was corrected by cementing aluminium foil $(1.0 \mathrm{~mm}$.) over the opening in the sliding bar sleeve within the electroscope chamber. About 30 per cent of the radiation of iodine was absorbed by this filter. Constant backgrounds were obtained by this method. Fluctuations of 0.000045 to 0.000055 divisions per second in 6 to 10 hours occurred.

The accuracy of tissue analyses for radioactive iodoprotein, using the hydrolytic and evaporation technic, was markedly improved over that for radiobromoprotein, for which the oxidation and silver salt precipitation method was used $(1,2)$. Tables I and II show the error of the hydrolytic and evaporation technic and may be compared to similar data for bromoprotein in Tables II and III of Paper III (2).

\section{RATE OF DISAPPEARANCE OF RADIOACTIVE PLASMA PROTEIN CONTAINING RADIO- ACTIVE IODINE FROM THE PLASMA OF NORMAL DOGS}

In each experiment described below, the rate of disappearance of the radio-iodo plasma protein from the circulation was observed in a normal morphinized dog. Fairly uniform results were obtained. A composite curve of several such experiments is shown in Figure 1 and may be compared with disappearance curves for radiosulfprotein and radiobromoprotein shown in Figure 1 of Paper IV (1). The greatest rate of disappearance (10 to 25 per cent) occurs during the first hour after injection. The subsequent rate of disappearance is about 2 per cent per hour. In 4 dogs of this group, the average loss of Evans Blue
TABLE II

Comparison of measurements of $1.0 \mathrm{gram}$ samples of various tissues to each of which was added a constant amount of radioactive iodoprotein

\begin{tabular}{|c|c|c|c|c|c|c|}
\hline Tissue & $\begin{array}{l}\text { Radio- } \\
\text { activity }\end{array}$ & $\begin{array}{c}\text { Devia- } \\
\text { tion } \\
\text { from } \\
\text { linearity }\end{array}$ & $\begin{array}{c}\text { Dry } \\
\text { residue } \\
\text { weight }\end{array}$ & $\begin{array}{l}\text { Radio- } \\
\text { activity }\end{array}$ & $\begin{array}{c}\text { Devia- } \\
\text { tion } \\
\text { from } \\
\text { linearity }\end{array}$ & $\begin{array}{l}\text { Dry } \\
\text { residue } \\
\text { weight }\end{array}$ \\
\hline & $\begin{array}{l}\text { divisions } \\
\text { per } \\
\text { second }\end{array}$ & per cent & mgm. & $\begin{array}{l}\text { divisions } \\
\text { per } \\
\text { second }\end{array}$ & per cent & mgm. \\
\hline $\begin{array}{l}\text { Liver } \\
\text { Lung } \\
\text { Bowel } \\
\text { Skin } \\
\text { Muscle } \\
\text { Kidney }\end{array}$ & $\begin{array}{l}0.00303 \\
0.00292 \\
0.00255 \\
0.00281 \\
0.00292\end{array}$ & $\begin{array}{r}0 \\
-4 \\
-17^{*} \\
-8 \\
-4\end{array}$ & $\begin{array}{l}650 \\
640 \\
735 \\
635 \\
670\end{array}$ & $\begin{array}{l}0.00150 \\
0.00150 \\
0.00148 \\
0.00109 \\
0.00154 \\
0.00146\end{array}$ & 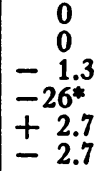 & $\begin{array}{l}810 \\
685 \\
745 \\
980 \\
705 \\
820\end{array}$ \\
\hline
\end{tabular}

* A large amount of fat in these specimens was hydrolysed to soap. Due to the great viscosity of the solution, pipette drainage was not complete. A small error was also introduced by absorption of radiation by the greater dry weight.

from the circulating plasma during the first hour was 20 per cent.

\section{DETERMINATION OF INTRAVASCULAR PLASMA CONTENT OF TISSUES AND CALCCULA- TION OF PLASMA LEAKAGE}

"In addition to curves of disappearance from the circulation of radioiodoprotein, the tissue content of radioactive protein was determined simultaneously. This is necessary because it is not possible to calculate whole plasma loss from blood disappearance curves unless the plasma volume is known with certainty. Since all methods of measuring plasma volume, which depend on dilution of a dye or tagged substance, measure only circulating plasma, reliable calculations of plasma loss are not possible by such techniques under all circumstances, especially during the shock state. The determination of the protein which has actually left the circulation, by analysis of the tissue content of radioactive protein, constitutes a method independent of plasma volume measurements. This method also provides a means of determining whether or not a preferential leakage into certain areas occurs" (5).

In order to calculate the extravascular plasma protein content, the radioactivity due to intravascular radioactive plasma protein was subtracted from the total tissue radioactivity, as measured directly. The intravascular plasma content of tissues (and its radioactivity) was calculated from the hemoglobin content of each tissue and of arterial blood (at the time of death), and the estimated capillary blood hematocrit from equations (1), (2), and (3), derived as follows:

Since

hemoglobin content of tissue blood

hemoglobin content of arterial blood

$=\frac{\mathrm{ml} \text {. red blood cells per gram tissue }}{\mathrm{ml} \text {. red blood cells per } \mathrm{ml} \text {. blood }}$ 


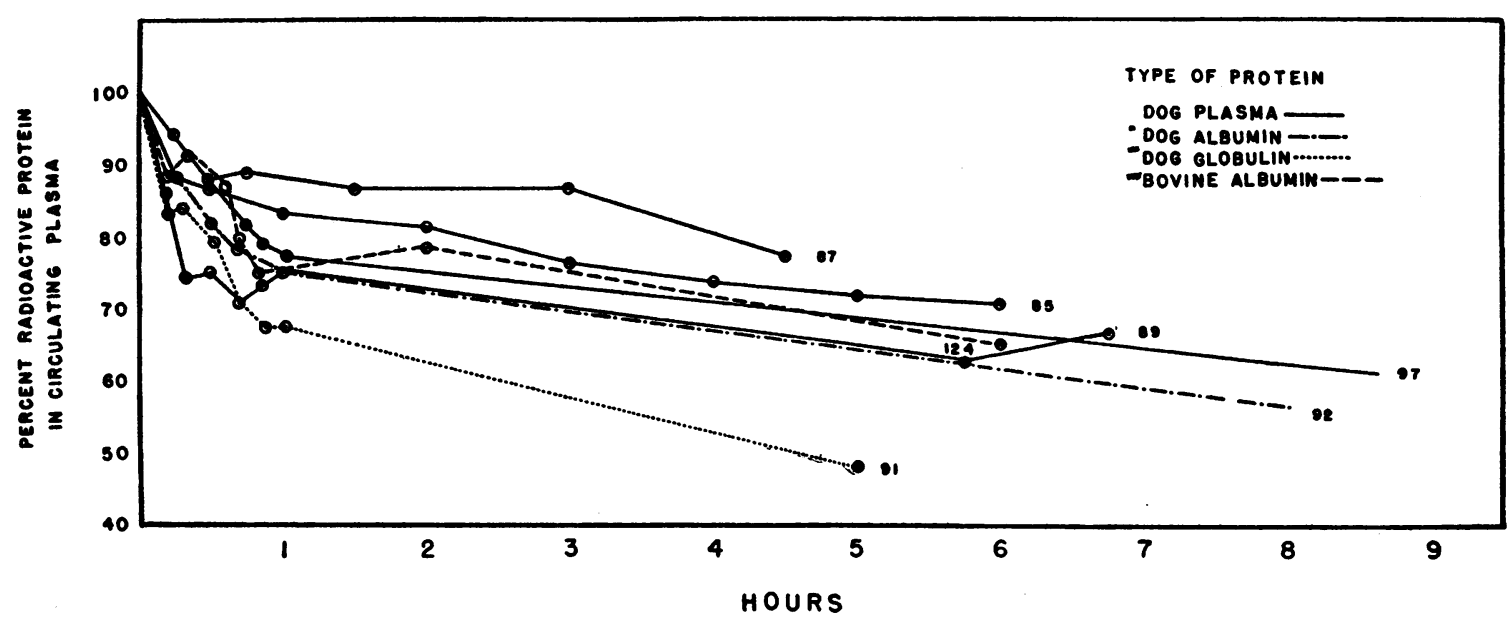

Fig. 1. Rate of Disappearance of Radioactive Iodoprotein from the Circulating Plasma of normal Dogs. Dog Numbers are Given with Each Curve.

x Mostly albumin but contained some globulin.

$\mathbf{x x}$ Globulin was precipitated by prolonged dialysis and was redissolved with the aid of sodium carbonate.

xxx Prepared from crystallized bovine albumin provided through the courtesy of Prof. E. J. Cohn, Department of Physical Chemistry, Harvard Medical School.

and

$$
\frac{\text { ml. red blood cells }}{\text { hematocrit }}=\mathrm{ml} \text {. blood }
$$

then

hemoglobin content of tissue blood

hemoglobin content of arterial blood

$$
\times \frac{\text { hematocrit arterial blood }}{\text { hematocrit tissue blood }}=\frac{\mathrm{ml} \text {. blood }}{\text { gram tissue }}
$$

and

$\frac{\text { ml. blood }}{\text { gram tissue }} \times(1-$ hematocrit of tissue blood $)$

$$
=\frac{\mathrm{ml} \text {. plasma }}{\text { gram tissue }}
$$

or

hemoglobin content tissue blood hemoglobin content art. blood

$$
\times\left(\frac{\text { hemat. art. blood }}{\text { hemat. tissue blood }}-\text { hemat. art. blood }\right)
$$

$$
\frac{\text { ml. plasma }}{\text { gram tissue }}=R(K-\text { arterial hematocrit })
$$

where

$$
K=\frac{\text { hematorr } \iota \text { of arterial blood }}{\text { hematocrit of tissue blood (capillary) }}
$$

and

$$
\text { (3) } \quad \mathrm{R}=\frac{\text { hemoglobin content of tissue blood }}{\text { hemoglobin-content of arterial blood }}
$$

Previous studies (8) showed that the average body hematocrit (as determined by radioactive red cells tagged with radioactive iron) was almost never greater than the arterial hematocrit in normal, exsanguinated, or shocked dogs. Simple calculations from these 2 determined hematocrits, and the fact that about 15 per cent of the blood volume is present in the capillary bed, indicated that the ratio (K) $\frac{\text { hematocrit of arterial blood }}{\text { hematocrit of tissue blood }}$ was about $4 / 3$. Therefore the number 1.33 was used for $\mathrm{K}$ in applying the formula given above. Undoubtedly $K$ is not a constant from dog to dog or from tissue to tissue in the same dog, but as an approximation, no great error was introduced by the assumption of an arbitrary value for $K$ in the final calculation of leakage. This is shown by the following considerations:

The loss of radioactive plasma from the blood vessels in ml. per gram of tissue was determined by subtracting the extravascular radioactivity per gram tissue of the control dog from that of the shocked dog, divided by the unit activity of plasma of the shocked dog. The extravascular radioactivity was determined from the total tissue radioactivity (A) as measured minus the intravascular radioactivity. This latter was determined from equation (1) as the intravascular plasma content of the tissue multiplied by the unit radioactivity of circulating plasma at the time of death. The following equation results:

(4) Loss in ml. per gram

$$
=\frac{\left[A_{0}-R_{0} a_{0}(K-H)_{0}\right]-\left[A_{0}-R_{0} a_{0}(K-H)_{0}\right]}{a_{0}}
$$


where $A$ is total measured radioactivity of 1.0 gram of tissue

$$
\begin{aligned}
\mathbf{R} & =\frac{\text { hemoglobin content of tissue blood }}{\text { hemoglobin content of arterial blood }} \\
\mathbf{a} & =\text { unit activity of plasma at time of death } \\
\mathbf{K} & =\frac{\text { hematocrit of arterial blood }}{\text { hematocrit of tissue blood }} \\
\mathbf{H} & =\text { arterial hematocrit }
\end{aligned}
$$

The subscripts $c$ and $s$ refer to control and shocked dogs respectively.

Rearrangement of equation (4) gives

(5) Loss in ml. per gram

$$
=\frac{\left(A_{s}-A_{0}\right)-R_{0} a_{0}(K-H)_{0}+R_{0} a_{0}(K-H)_{0}}{a_{\bullet}}
$$

If the average body hematocrit is never greater than the arterial hematocrit, $K$ will never be less than 1.0. If in equation (5) deviations from the assumed value for $\mathrm{K}$ of 1.33 should vary, the error introduced by $K$ varying between 1.0 and 1.5 still can never be great and will tend to cancel out because the hematocrit (usually between 0.2 and 0.8 ) will not exceed $K$ and therefore not reverse the signs in equation (5). In normal dogs, $(\mathrm{K}-\mathrm{H})_{\mathrm{e}}$ is about equal to 1 and in shocked dogs, $(\mathrm{K}-\mathrm{H})$, could only possibly vary between 0.2 and 1.3 with but a small effect on the final calculations.

As a further precaution to reduce the error from calculations of intravascular blood to a minimum, dogs were exsanguinated at the end of the experiment, and, in isolating tissues for analysis, excess blood and large vessel blood was gently wiped from each piece of tissue. In this way, the intravascular content of blood was reduced to a minimum and as far as possible represented blood in capillaries and very small vessels.

\section{DETERMINATION OF HEMOGLOBIN CONTENT OF TISSUES}

Tissues for both radioactivity analysis and hemoglobin determinations were taken from representative areas of each organ and pooled. Skin after shaving was taken from neck, thorax, back, foreleg, and hindleg. Muscle was taken from neck, back, foreleg, and hindleg. Intestine was taken from stomach, small intestine, and colon, after removing the fatty mesenteric border. Lung was taken from several lobes. Damaged legs (tourniquet or burn) were boned and minced in a meat grinder and aliquots taken. The tissues were cut into cubes about 0.5 to 1.0 $\mathrm{cm}$. in diameter and mixed. Four grams were weighed out for radioactivity analysis as described above. Two grams were weighed out for hemoglobin analysis. Muscle and heart were covered with physiological saline and the other tissues with water $(40 \mathrm{ml}$.). The pieces were finely minced with a scissors and allowed to remain overnight in the icebox. In the case of muscle and heart, the residue after centrifugation was extracted with water (9). The suspensions were then filtered through gauze, cleaned with ammonia, diluted with water, and measured in a photoelectric colorimeter (Klett) against standards from arterial blood (taken at the time of death), using 540,620, and 660 filters. In order to correct for turbidity, the 620 and 660 filter readings were plotted and extrapolated to 540 (9). The value so obtained was subtracted from the reading obtained with the $\mathbf{5 4 0}$ filter and substituted in equation (6) below. Standards were prepared from blood diluted 1000 times and treated in the same way. Since 2.0 grams of tissue were used, the ratio $R$ (equation (3)) is calculated from:

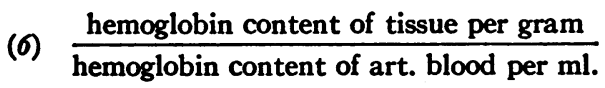

$$
=\frac{\text { dilution factor } \times \text { reading for tissue }}{2 \times 1000 \times \text { reading for standard }}
$$

Since it was found that the extrapolation method with both filters 660 and 620 gave results but slightly different from those obtained with the $\mathbf{6 2 0}$ filter alone, the latter filter was used in the majority of the analyses. The reading as obtained was subtracted from that found with the $\mathbf{5 4 0}$ filter.

Although inaccuracies in the hemoglobin measurements are unavoidable, due to methemoglobin formation, turbidity, incomplete extraction of tissue, and possibly other factors, the red cell volume in $\mathrm{ml}$. per gram of tissue by this method agreed sufficiently well with simultaneous red cell volume determinations made by the radioiron red cell technic ${ }^{7}$ to permit acceptance of the hemoglobin method as a good enough approximation to the facts (cf. Table VI of previous publication (5)).

\section{RESULTS}

\section{A. Hemorrhagic shock}

In experiments with radiobromoprotein (1), the plasma loss in hemorrhagic shock was found not to exceed that of the normal dog. In the following experiments, plasma loss into tissues of the dog in irreversible shock (i.e., not lastingly responsive to a transfusion of all blood removed) is compared with that of a dog in reversible shock (i.e., responsive to a transfusion of all blood removed).

Experiment No. I-7: Two dogs (Nos. 98 and 99) were bled into shock by a hemorrhage of 4.1 per cent and 2.7 per cent of the body weight, respectively. After 7.5 hours in shock, when the blood pressure was $20 \mathrm{~mm}$. $\mathrm{Hg}$, Dog No. 98 was given a transfusion of dog plasma (4.5 per cent of the body weight) containing radioiodoprotein. At the same time, a transfusion of dog plasma (3.7 per cent of the body weight)

\footnotetext{
7 In collaboration with Gibson and Peacock (8).
} 
containing radioiodoprotein was given to Dog No. 99, which had been in shock for 3 hours, when the blood pressure was $30 \mathrm{~mm}$. $\mathrm{Hg}$. The same quantity of radioiodoprotein was given to each dog in proportion to the body weight. Dog No. 98 did not recover, and when the blood pressure again declined to $25 \mathrm{~mm}$. $\mathrm{Hg}$, the blood pressure of Dog No. 99, which was recovering, was $100 \mathrm{~mm} . \mathrm{Hg}$. Both dogs were exsanguinated 3 hours after their transfusion. Dog No. 98 yielding a volume of blood which was 0.67 per cent and Dog. No. 99, 2.5 per cent of the body weight. Tissue samples for analysis were taken immediately from both, with results shown in Table III, in which the ratio of radioactivity content per gram of tissue of Dog. No. 98 (irreversible shock) to that of Dog No. 99 (reversible

TABLE III

Ratio of radioactivity (radioiodoprotein) of tissues of dog in irreversible hemorrhagic shock as compared to control dog in reversible hemorrhagic shock, including plasma loss in whole organs in shocked (irreversible) as compared to control (reversible shock) dog*

Experiment I-7

\begin{tabular}{lcc} 
Tissue & $\begin{array}{c}\text { Ratio } \\
\text { per cent }\end{array}$ & $\begin{array}{c}\text { Plasma loss } \\
\text { ml. }\end{array}$ \\
Liver & 13 & 0 \\
Lung & 32 & 0 \\
Kidney & 87 & 0 \\
Intestine & 68 & 0 \\
Spleen & 112 & 1 \\
Skin & 41 & 0 \\
Heart & 62 & 0 \\
Muscle & 121 & 9.5 \\
\multicolumn{1}{c}{ Total } & &
\end{tabular}

* When radioiodoprotein is used, any ratio below 95 or above 105 , except in muscle, is taken to represent a difference outside of experimental error. This error is much smaller than in the case of radiobromoprotein $(1,2)$. The significance of such ratios is not evident in the ratio figures themselves since two factors of importance affect the calculation. These are the relative weights of the organ and the relative radioactivity measurements of such organs per gram. For example, if a ratio of 200 , derived from a radioactivity of 0.001 div. per sec. On the electroscope in the control and a radioactivity of 0.002 div. per sec. in the shocked dog, applies to a gram of tissue of a given organ (A); and the same ratio derived from a radioactivity of 0.0001 div. per sec. in the control and 0.0002 div. per sec. in the shocked dog, applies to a gram of tissue of another organ (B) of the same weight, the difference in radioactivity per gram of tissue will be 0.001 for organ $A$ and 0.0001 for organ B. The total radioactive protein content of organ $A$ will be ten times that of organ $B$ and the quantitative loss involved is obviously far less in organ B, even though the ratio is the same for both. The relative activities of various tissues in normal dogs are shown in another publication (1). The quantitative significance of an increased ratio is of little consequence in an organ like the kidney, which is small in weight, and the same is true when a large organ has a very low order of radioactivity. shock) is given, as well as the plasma loss in $\mathrm{ml}$. per whole organ, calculated from the difference in extravascular radioiodoprotein content per gram of tissue between Dogs Nos. 98 and 99; i.e., the excess of radioiodoprotein in the tissues of Dog No. 98.

Since the unit activity of circulating plasma found at the end of the experiment was used in calculating the volume of plasma loss, the values for loss obtained represent the greatest possible loss and are probably high.

Except for muscle and spleen, all the tissues of Dog No. 98 contained less extravascular plasma than those of Dog No. 99. There is, accordingly, no evidence of greater leakage of plasma in the dog in irreversible hemorrhagic shock as compared to the dog in reversible shock. On the contrary, the former, probably because of less efficient capillary circulation, seems to have displayed a slower rate of escape of iodoprotein from the circulation.

Since no significant leakage of plasma was noted following a plasma transfusion in irreversible hemorrhagic shock, it was considered desirable to see whether plasma leakage was significantly increased by a subsequent saline infusion, which is widely held to be responsible for washing protein out of the circulation.

Experiment No. I-9. Two dogs (Nos. 122 and 123) were bled into shock by a hemorrhage of 3.8 per cent and 4.0 per cent of the body weight, respectively. After 5 hours in shock, when its blood pressure was $30 \mathrm{~mm}$. $\mathrm{Hg}$, Dog No. 122 was given a transfusion of all shed blood, containing $20 \mathrm{ml}$. radioiodoalbumin (bovine) with a pressor response to $90 \mathrm{~mm}$. $\mathrm{Hg}$. Four hours later the blood pressure was $45 \mathrm{~mm}$. $\mathrm{Hg}$. Since the dog was in "irreversible" shock, a saline infusion of $1500 \mathrm{ml}$. was given. This resulted in a maximum rise in blood pressure to $95 \mathrm{~mm}$. $\mathrm{Hg}$, with a subsequent decline to $60 \mathrm{~mm}$. $\mathrm{Hg}$, three and one-half hours later when the dog was exsanguinated (500 ml.). All tissues were edematous and there were slight hemorrhages in the jejunum and colon. Radioactive red cells were injected (8) and the tissues were analyzed for blood content on the basis of radioactive iron content. These data will be published elsewhere.

After 2 hours in shock, with a blood pressure of $65 \mathrm{~mm} . \mathrm{Hg}$, Dog No. 123 received all shed 
blood containing $26 \mathrm{ml}$. of radioiodoalbumin (bovine). Four hours later, the blood pressure was $100 \mathrm{~mm}$. $\mathrm{Hg}$. This dog was therefore reversible. A saline infusion of $2000 \mathrm{ml}$. was then given. The pressure rose to $140 \mathrm{~mm}$. $\mathrm{Hg}$ and three and one-half hours later was $90 \mathrm{~mm}$. $\mathrm{Hg}$ when the dog was exsanguinated $(600 \mathrm{ml}$.). All tissues were edematous and there were slight hemorrhages in the jejunum.

As a further control for comparison, a normal dog (Dog No. 124) was given $24 \mathrm{ml}$. of radioiodoalbumin (bovine). Four hours later, 1500 $\mathrm{ml}$. saline were given intravenously and three and one-half hours later the dog was exsanguinated $(1150 \mathrm{ml}$.).

Radioiodoalbumin was given in proportion to body weight in all but this control dog. Correction for this was made in the final calculations. The hemorrhagic jejunum of Dog No. 123 was analyzed separately for plasma content per gram and found to be about the same as for the rest of the intestine in terms of total radioactivity and less on the basis of extravascular radioactivity.

If the calculated final total plasma volumes of these 3 dogs (all of which received equivalent saline infusions) is taken to equal 10 per cent of their respective body weights minus the blood removed plus the volumes of blood and saline infusions, the tissue radioactivity data show that the loss in plasma volume of the irreversibly shocked dog was 10 per cent greater than in the normal dog and the loss of the reversibly shocked dog 3 per cent greater than in the normal dog. One must conclude, therefore, that saline infusion increases the leakage of plasma protein in shock and more markedly in irreversible shock. The tissues showing most significant leakage were muscle, intestine, lung, and liver (Table IV). However, it is unlikely that the loss of 10 per cent of the plasma volume after the large saline infusion in the irreversibly shocked dog was responsible for the subsequent decline in blood pressure, especially since the blood pressure had previously declined to $45 \mathrm{~mm}$. $\mathrm{Hg}$ following whole blood tranfusion.

"Since the forces operating to produce lethal shock are not necessarily the same in all types of shock, it became necessary to obtain data on the question of generalized increase in capillary permeability in conditions other than hemor-
TABLE IV

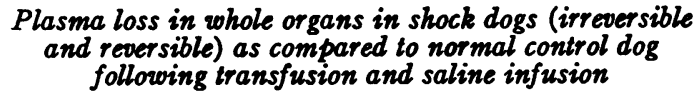

Experiment no. I-9

\begin{tabular}{lrr} 
Tissue & \multicolumn{2}{c}{ Plasma loss } \\
& $\begin{array}{c}\text { Irreversible. } \\
\text { Dog no. 122 }\end{array}$ & $\begin{array}{c}\text { Reversible. } \\
\text { Dog. no. 123 }\end{array}$ \\
Liver & 23 & ml. \\
Lung & 23 & 49 \\
Kidney & 33 & 2 \\
Intestine & 10 & 0 \\
Spleen & 27 & 41 \\
Skin & 3 & 0 \\
Heart & 4 & 4 \\
Muscle & 0 & 0 \\
\multicolumn{1}{c}{ Total } & 140 & 0 \\
\hline
\end{tabular}

rhage. Tourniquet shock and burn shock differ from hemorrhagic shock in that (1) a local loss into areas of injury occurs and (2) such injured tissues perhaps may liberate a substance capable of affecting capillary permeability in general" (5).

\section{B. Tourniquet shock.}

A tourniquet was applied at the groin to one or both legs of a dog under morphine $(3 \mathrm{mgm}$. per kgm.) and left on for 5 to 10 hours. Plasma volume was then measured and radioiodoprotein was given to this dog and to a normal morphinized dog in equivalent amounts. The tourniquet was removed and the same measurements as in Experiment I-7 made. Protocol data are given in Table V. Table VI lists the results of tissue analyses of 4 dogs (I-2A, I-2B, I-3, and I-4) showing plasma protein loss in various tissues including the tourniqueted extremities. While the results indicate loss of protein into some tissues other than the extremities, such loss involves only 1 to 3 tissues and in no case is the total loss outside of the extremities quantitatively significant, from the point of view of plasma protein depletion. There is, therefore, no evidence that a change in permeability to proteins, outside the area of injury, if it exists, is of consequence in the development and progression of shock following the removal of a tourniquet.

The volume of plasma lost into the tourniqueted extremities is of course large. The gain in weight was not determinable in Experiments I-2A and I-2B, where both legs were injured, but in Experiments I-3 and I-4 the weight increase (above the opposite normal leg) was much 
greater than the plasma gain determined by radioactivity assay of the tissues (Table $V$ ). The discrepancy is far in excess of errors in method. The difference, therefore, in major part, represents a gain in tissue water drawn from outside areas.

The plasma gain in the injured extremities in 3 of the 4 shocked dogs listed in Table VI is significantly less than the plasma loss found by circulating plasma volume determinations (Table V). It was pointed out elsewhere (1) that in deep shock, plasma volume measurements by the dye technic may overestimate loss because the segregation of more plasma into the stagnant peripheral bed as shock deepens (a progressive rise in the amount of trapped plasma) will increase the extent of incomplete mixing and so give too low a dye dilution figure in terms of the total plasma volume. Hence one may expect a discrepancy between the dye method and the tissue radioactivity method, the former showing a falsely higher loss, the more stagnant the peripheral bed becomes. But the much greater total fluid loss into the leg, found by actual weight change, than is disclosed by the dye method again points to a large access of tissue water derived from extravascular sources.

\section{Burn shock}

Three experiments were performed in which one or more extremities were immersed under ether anesthesia for varying intervals in water at $98^{\circ} \mathrm{C}$. (Tables V and VI). In Experiments I-5 and I-6, radio-iodoprotein was injected intravenously into a normal $\mathrm{dog}$ and into the burned dog before the burn was produced. In Experiment I-8, the technic was varied in order to see whether the capillaries were more permeable to protein in a severely burned than in a mildly burned animal. For this purpose, 2 dogs were burned, one for 120 seconds, the other for 20 seconds. Four hours before death of the

TABLE V

Protocol data in tourniquet shock and burn shock and comparison of plasma loss into injured extremity by three criteria

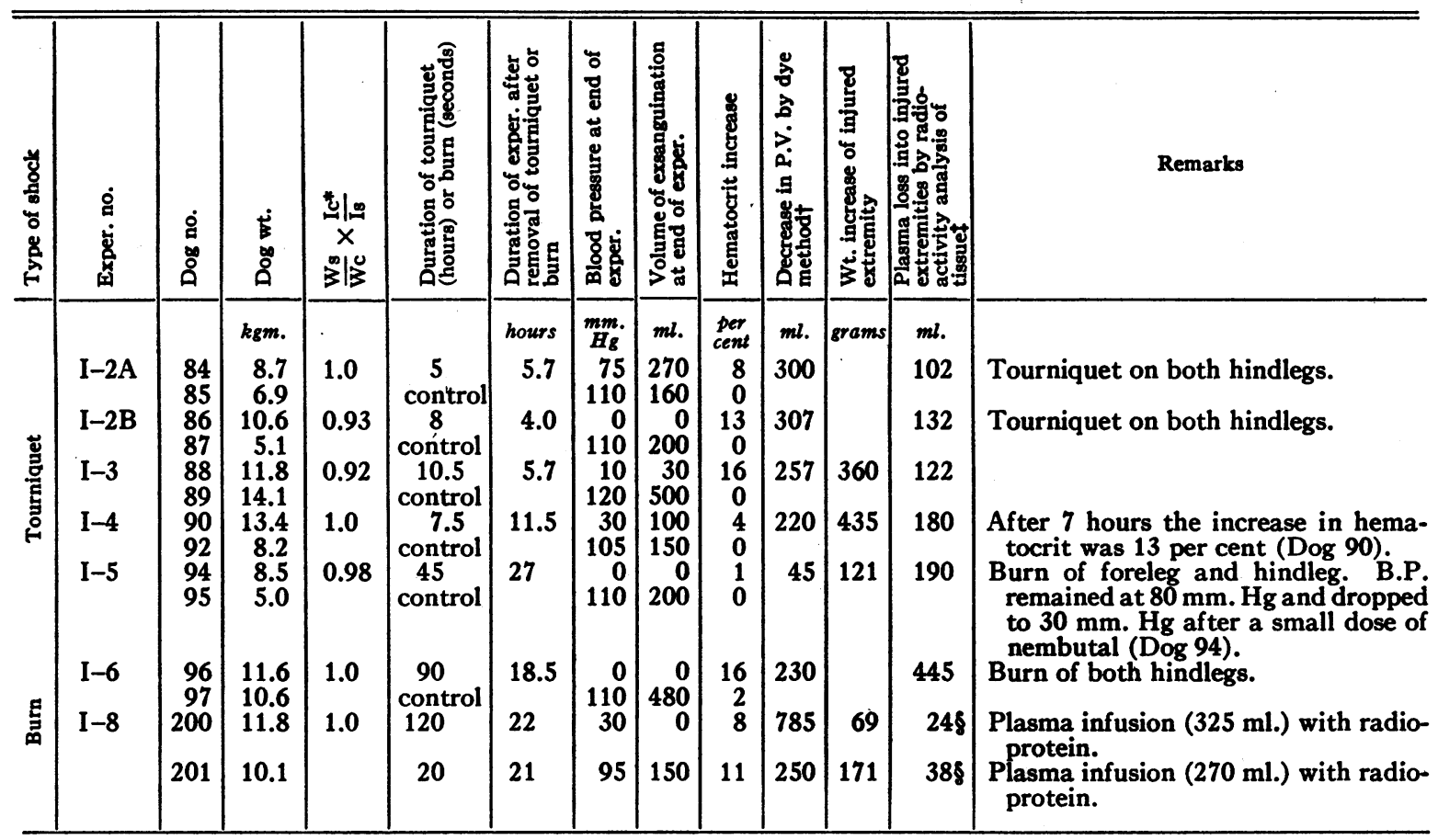

* Formula showing relative proportion of radioprotein dosage to weigh of shocked versus control dog, when $\mathrm{W}=\mathrm{wt}$. of $\operatorname{dog}, I=$ volume of radioactive plasma injected, $c=$ control $\operatorname{dog}$ and $s=$ shocked $\operatorname{dog}$.

f In burn experiments, plasma volumes by dye method were complicated by marked hemolysis.

†ata from Table VI.

Since tagged infusion was given four and one-half hours before end of experiment, loss during this period only was determined. 
more severely burned dog, a plasma infusion containing radio-iodoprotein was given simultaneously to both dogs.

The extravascular radioactive protein content of the tissues in all 3 experiments showed no significant loss in the plasma protein content of the unburned tissues of the burned dog in comparison with the same tissues in the unburned control dog (Experiments I-5 and I-6) or the less severely burned control dog (Experiment I-8).

In Experiment I-5 and I-6, there is no correspondence between the plasma volume loss into the burned extremity, as determined from radioactive plasma protein content, and the loss as measured by intravenous dye. The unavoidable hemolysis of blood in burned dogs affects the reliability of the latter method.

In Experiment I-8, the radioactive protein content was injected too late to permit a determination of total plasma protein loss into the burned area. In the severely burned dog, the very small increase in weight of the burned extremity suggests that peripheral vascular collapse was due to factors other than plasma volume deficiency.

Although the extent of the plasma protein loss into the tissues in the foregoing experiments cannot be assessed with complete accuracy $( \pm 10$ to 15 per cent), the loss outside of areas of injury involves only 1 or 2 tissues, which vary from one experiment to another, and, in any case, is not quantitatively significant.

The calculation of plasma volume loss into tissue is based on the assumption that if such loss occurs outside of areas of local injury, whole plasma is lost. If greater capillary permeability to the non-protein than to the protein fraction of the plasma should exist, the disproportion between the loss of the protein and the nonprotein fraction of plasma would be reflected in a shift of the total protein concentration. Since the latter does not increase in hemorrhagic shock (5), plasma if lost would be in proportion to protein loss in hemorrhagic shock, except perhaps when saline infusions are given in the late shock phase. The rise in total protein concentration in burn shock and in tourniquet shock may be explained as due to a disproportionate loss of the non-protein fraction into or outside the injured area. Such loss, if substantial, into
TABLE VI

Plasma loss in whole organs of dogs in tourniquet or burn shock as compared to control dogs

\begin{tabular}{|c|c|c|c|c|c|c|c|}
\hline \multicolumn{8}{|c|}{ Plasma loss } \\
\hline \multirow{2}{*}{ Exper. no. } & \multicolumn{4}{|c|}{ TOURNIQUET SHOCK } & \multicolumn{3}{|c|}{ BURN SHOCK } \\
\hline & $\mathbf{I}-2 \mathrm{~A}$ & I-2B & I-3 & $I-4$ & I-5 & $I-6$ & $I-8 *$ \\
\hline $\begin{array}{l}\text { Liver } \\
\text { Lung } \\
\text { Kidney } \\
\text { Intestine } \\
\text { Spleen } \\
\text { Stin } \\
\text { Heart } \\
\text { Muscle } \\
\text { Injured extremities } \\
\text { Totals }\end{array}$ & $\begin{array}{l}m l . \\
0 \\
0 \\
1.3 \\
33 \\
2 \\
3.6 \\
0 \\
0 \\
102 \\
143\end{array}$ & $\begin{array}{l}m l . \\
0 \\
0 \\
0 \\
0 \\
0 \\
3.5 \\
0.4 \\
43 \\
132 \\
179\end{array}$ & $\begin{array}{l}m l . \\
2.6 \\
7 \\
0.7 \\
0 \\
0.4 \\
0 \\
0 \\
7 \\
122 \\
140\end{array}$ & $\begin{array}{l}m l . \\
0 \\
2 \\
0 \\
0 \\
1.4 \\
0 \\
0 \\
\mathbf{3} .5 \\
180 \\
184\end{array}$ & $\begin{array}{c}m l . \\
0 \\
0 \\
2.1 \\
20 \\
0.7 \\
0 \\
0 \\
0 \\
190 \ddagger \\
213\end{array}$ & $\begin{array}{r}m l . \\
0 \\
0 \\
0 \\
0 \\
0 \\
5 \\
0 \\
7 \\
445 \dagger \\
457\end{array}$ & $\begin{array}{r}m l . \\
15 \\
9 \\
0 \\
0 \\
0 \\
3 \\
0 \\
10 \\
24 \ddagger \\
61\end{array}$ \\
\hline
\end{tabular}

* The control dog in this experiment was also burned, one more severely than the other to compare severe and mild burn shock states.

t If loss of plasma is assumed to have occurred early after the burn, these values would be halved.

$\mp$ Plasma loss into the burned legs was calculated by comparison with values for intact muscle and skin for both dogs. Plasma loss in milder burn was $38 \mathrm{ml}$. Small loss was due to the fact that leakage occurred before radioiodoprotein was given (four and one-half hours before the end of the experiment).

tissues outside the injured area, would not be likely without a loss of a measurable amount of protein. Since no protein is lost (i.e., no loss of consequence, except in a sporadic and inconsistent manner involving 1 or 2 tissues varying from one experiment to another) into areas outside the locally traumatized area in either burn shock or tourniquet shock, our assumption that no plasma is lost outside of areas of local injury seems justified. Evidence indicates that water is drawn from outside areas and lost into the injured areas, i.e., uninjured areas are dehydrated.

\section{COMMENT}

The foregoing evidence does not support the idea of capillary permeability causing leakage of plasma from the blood to the tissues except in localized areas of injury. The widespread belief that the capillaries throughout the body "leak" plasma is presumably based on the common observation in man and animals, dead of shock, that the tissues are wet or hemorrhagic. While saline infusions in particular will facilitate an increased rate of escape of plasma protein, further evidence is provided in another publication (10) that such leakage is the result of therapy and is not seen in untreated shock, except in the case 
of intestinal bleeding in burns. But even in burns, it remains to be shown that hemorrhage into the intestine or elsewhere is of a sufficient order of magnitude to contribute seriously to the hemodynamic deficiency caused by the local plasma loss in the burned area. A change in permeability of the general capillary bed, whether it exists or not, cannot be said to bear any relation to the shock syndrome. Saline therapy causes some loss of plasma protein into tissues. To what extent the shock state is thereby altered cannot be assessed.

The evidence is clear also that when the deficient plasma volume due to loss into an area of injury is corrected, circulatory collapse is not due to a progressive decline in plasma volume from leakage of plasma outside of the area of injury. While a decline in effective circulating volume may occur during this subsequent phase of circulatory collapse, it is due in part to continued leakage into the injured area and in part to progressive peripheral stagnation. In irreversible hemorrhagic shock, death ensues even when blood or plasma is given so as to produce a plethora. Since leakage of plasma from the generalized capillary bed does not occur, it is not the cause of death.

\section{CONCLUSIONS}

1. Plasma proteins tagged with radioactive iodine were used to study the capillary leakage hypothesis in hemorrhagic, tourniquet, and burn shock. No evidence of leakage due to a change in the permeability of the generalized capillary bed was found. Tagged plasma proteins escaped into areas of injury in considerable amounts, but not into untraumatized areas. This was also true after plasma infusion.

2. There is also evidence to show that the general capillary bed does not become more permeable to plasma proteins or plasma in the late or irreversible phase of hemorrhagic shock following transfusion.
3. Following saline therapy in hemorrhagic shock, plasma proteins are carried out of the blood stream with saline. This occurs to a greater extent in irreversible than reversible hemorrhagic shock. The volume of dilute plasma lost in this way is small.

Acknowledgment is made to Miss Martha Goldberg for technical assistance.

Radioactive iodine was prepared by the Radioactivity Center of the Massachusetts Institute of Technology.

\section{BIBLIOGRAPHY}

1. Fine, J., and Seligman, A. M., Traumatic shock. IV. A study of the problem of the "lost plasma" in hemorrhagic shock by the use of radioactive plasma protein. J. Clin. Invest., 1943, 22, 285.

2. Seligman, A. M., Traumatic shock. III. A modified electroscope especially suited for measuring substances with low energy radiation. J. Clin. Invest., 1943, $22,281$.

3. Seligman, A. M., and Fine, J., Traumatic shock. I. The production of radioactive plasma protein from amino-acids containing radioactive sulfur. J. Clin. Invest., 1943, 22, 265.

4. Seligman, A. M., Rutenburg, A. M., and Banks, H., Traumatic shock. II. The preparation of cystine, methionine, and homocystine containing radioactive sulfur. J. Clin. Invest., 1943, 22, 275.

5. Fine, J., and Seligman, A. M., Traumatic shock. An experimental study including evidence against the capillary leakage hypothesis. Ann. Surg., 1943, 118, 238.

6. Cope, O., and Moore, F. D., A study of capillary permeability in experimental burns and burn shock using radioactive dyes in blood and lymph. $\mathrm{J}$. Clin. Invest., 1944, 23, 241.

7. Hertz, S., Roberts, A., Means, J. H., and Evans, R. D., Radioactive iodine as an indicator in thyroid physiology. Am. J. Physiol., 1940, 128, 565.

8. Gibson, J. G., Seligman, A. M., and Peacock, W. To.be published.

9. Lowry, O. H., and Hastings, A. B., Histochemical changes associated with aging. I. Methods and calculations. J. Biol. Chem., 1942, 143, 257.

10. Fine, J., Frank, H. A., and Seligman, A. M., Traumatic shock. VIII. Studies in the therapy and hemodynamics of tourniquet shock. J. Clin. Invest., 1944, 23, 731. 